\title{
Maria Macuch and Iranian Studies
}

\author{
Almut Hintze
}

Maria Macuch is the daughter of the semitist Rudolf Macuch and IranDokнt Shaghaghi. ${ }^{1}$ Her parents met during the years 1945-1947 when students in Paris, where Rudolf studied Arabic and Semitic languages, and IRANDOKHT Hygiene at the Faculty of Medicine. Soon after their marriage on 31 March 1949 in Bratislava they transferred to Iran, and MARIA was born in 1 January 1950 in Tehran, where she spent the first six years of her life. In 1956 Rudolf Macuch received an invitation from Lady Drower to work with her on the Mandaic Dictionary at the Oriental Institute in Oxford and the family moved there in October of the same year. MARIA remembers this trip as the most exciting journey of her life, travelling by train from Tehran via Turkey across the European continent and a stormy English channel (MAcuch 2008a, p. 13). In Oxford Maria went to the SS Philip and James' Church of England Primary School, and her mother converted to Christianity. Life in Oxford has made an abiding impression on MARIA, and she never misses an opportunity to visit the city where she spent two very happy years of her childhood. After Rudolf Macuch's fellowship had come to an end, and since life in Iran seemed undesirable for a Christian convert, the small family moved to Windsor, Canada in 1958 and MARIA's father took up the position of a vicar. His dream of a university career eventually came true when he was invited to the Chair of Semitic and Arabic Studies at the Freie Universität Berlin. In 1963 the family moved to Berlin and Maria went to school at the Droste-Hülshoff-Gymnasium in Zehlendorf. Growing up as the only child of the acclaimed scholar of the Mandaean, Samaritan and Syriac languages has deeply influenced MARIA's own professional outlook and choices. "With his background in Oriental Studies and his life and work as a scholar”, she remembers in an interview (HinTzE 2014, p. 7),

my father set the example for me of how to do scholarly work. He was the most important influence on me. I saw daily how he worked all the time, how intensely he studied the subjects he was interested in. It was all work and no play-except with me. I couldn't imagine doing any thing else but scholarship because I hadn't

1 For MARIA's accounts of her father's life, see Macuch 2008a, 2014a, 2015a.-I am grateful to Desmond Durkin-Meisterernst and Maria Macuch herself for helpful comments on an earlier version of the present article. 
seen anything else. My mother, Irandokht, influenced my choice of subjects through her Iranian background, although, being a Christian by choice, she was not typically Iranian.

After her Abitur in 1969 Maria enrolled at the Freie Universität in Iranian Studies, Semitic languages and Ancient History. She was soon captivated by the pre-Islamic tradition of her mother's homeland, and this has become a lifetime's fascination. Among the many teachers whose lectures she attended were, in Iranian Studies, Carsten Colpe, Günter Gobrecht, Hans Kippenberg, Bernfried Schlerath, and, as guest professor, Ronald Emmerick, who taught an intensive course on Khotanese. In Semitic and Islamic Studies, she studied with Estiphan Panoussi, Benno Pohl, Zuhair Shunnar, Baber JoHANSEN and FRITZ STEPPAT. However, the scholar who was the most influential on the direction she would eventually take was one whom she never could have met. This was Christian Bartholomae (1855-1925), whose pioneering writings on Sasanian law drew MARIA into largely uncharted territory. Moreover, GÜNTER Gobrecht introduced her to the linguistic and philological problems of Middle Persian legal texts, and it was in this area that she obtained her PhD in 1977 (with Ruth Altheim-Stiehl as one of the examiners) and her Habilitation in 1990 (with Werner Sundermann and Philippe Gignoux as referees). After a year spent as Visiting Professor at the National Taiwan University in Taipei, Maria became Associate Professor (C3) at the Institut für Iranistik in Berlin in 1991. Having been offered the Chair in Iranian Studies (C4) at the Georg-August-Universität in Göttingen in 1994, she was able to take up the offer of the Chair in Iranian Studies at the Freie Universität Berlin in 1995 and held this position until her retirement in 2015. She now lives in Berlin and enjoys being able to focus on her research, free from administrative and teaching duties.

\section{A Thousand Judgements}

To date, MARIA's magnum opus is an edition in two volumes of the Sasanian law book 'A Thousand Judgements' (Hazār Dādestān). ${ }^{2}$ The transmission of this text is most precarious as it only survives in a single manuscript, which at some point in time was split into two parts. The first part consists of 55 folios published in facsimile by MoDi in 1901 (usually abbreviated MHD), and the second part of 20 folios made available in facsimile by Anklesaria in 1912 (usually abbreviated MHDA). ${ }^{3}$ MARIA's PhD thesis was concerned with the second part

2 On the title of the work, see Macuch 1993, p. 10f.

3 Anklesaria's folios were copied by Dastur Erachji Sohrabji Meherji Rana of Navsari in AY 1247 (1878 CE). His copy is preserved in the Meherji Rana Library under the signature F25 and is described by DhabHar 1923, p. 18. It was published in facsimile by JamaspAsa/Nawabi 1976. 
and was published in 1981. She tackled the first part in her Habilitation thesis, published in 1993 as the first volume in the series Iranica, which she founded. Taken together, these two works provide a monumental edition of the complete text. It is transliterated from the manuscript, translated and accompanied by an extensive philological and legal commentary, and a dictionary. The text 'A Thousand Judgements' has also fuelled most of MARIA's other scholarship and is a constant point of reference in her research.

The Hazār Dādestān was compiled by Farroxmard ì Wahrāmān from court records and other documents, probably in the early seventh century CE, just a few decades before the Arab invasion of Iran. Constituting the only exclusively legal text which has survived from the pre-Islamic period, it is of supreme importance for the history of Iranian law in Zoroastrian and Islamic Iran, and for the influence of Sasanian law, especially on Talmudic and Islamic law. Moreover, this text provides unique insights into everyday life in Sasanian Iran and into its social institutions, by documenting how legal matters were discussed and law was practised in the law courts. The text discusses complex hypothetical and actual legal cases and legal judgements in the areas of family law, property rights and procedural law, and was designed as a reference work for specialists who were familiar with both the legal system and its terminology. The system gradually broke down when in the course of the Islamization of Iran Zoroastrian law was replaced by Islamic law, and the Zoroastrian jurisdiction became restricted to family law and the rules regulating dealings with members of other religions. As a result, the knowledge and understanding of the Sasanian legal terminology gradually became obsolete and eventually fell entirely into oblivion (MACUCH 2012a, p. 523f.). Although other contemporary iranists have also made important contributions to the study of Sasanian law, in particular the Russian (of Armenian origin) Anahit Perikhanian (1928-2012) and the Danish Bodil HJerRild (b. 1942), it was Maria Macuch who noticed most clearly that the Pahlavi legal texts use a very precise and compact terminology that needs to be unlocked before these texts can be translated. She identified it as her two-fold task to define the exact meaning of the numerous technical terms found in the Zoroastrian legal texts, and on that basis to reconstruct the underlying system of Sasanian law, the unwritten code which is a constant point of reference for the Sasanian jurists, but which is nowhere set out in a systematic fashion in our extant sources. Three major subject areas are particularly prominent in her publications: Sasanian Zoroastrian law, comparative law and Iranian literature. Her works on Sasanian law focus on legal terminology, Zoroastrian family law and the legal system, while those on Iranian literatures cover both Zoroastrian and Classical Persian literature. 


\section{Sasanian legal terminology}

Maria Macuch's studies on Zoroastrian legal terminology aim at unlocking and extracting the meanings and definitions of individual legal technical terms from the various contexts in which they occur. She identifies three types of source, all of which need to be employed for this undertaking (MACUCH 2005a, p. 375f., 2012a, pp. 519-525). The first are Pahlavi texts which are translations, commentaries or summaries of the Avesta. They include the Pahlavi versions of

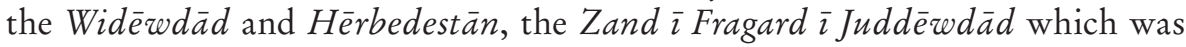
rediscovered by GöTz KöNIG (KöNIG 2010, p. 119), and the summary of the legal Nasks of the Avesta in Book 8 of the Dénkard. The second group consists of Pahlavi law books, or dādestān-nāmag. These texts are exclusively concerned with legal matters and must have been numerous in Sasanian times, although the only surviving sample is the Hazār Dādestān. To this category also belong original Pahlavi documents written on leather, cloth and other materials, since some of these have legal content (MACUCH 2008c), and the unique original court records from Tabarestān, on which MAcuch has collaborated with DiETER Weber (Macuch 2016b, 2017b). Written in Pahlavi cursive script and dating from $737 \mathrm{CE}$, the documents testify to the legal practice of the Sasanian juridicial system. They provide unprecedented insights into the work of the law courts in Tabarestān and how law cases were recorded and documented. The third type is the Pahlavi literature, in particular the Dādestān $\bar{\imath}$ dènīg, the Rivāyat $\bar{\imath}$ Adurfarnbay and Farnbag-Srōšs, the Rivāyat $\bar{\imath} \bar{E} m \bar{e} d \bar{\imath} A$ šawabistān and other texts. Many of the Middle Persian legal terms originate from the Avesta and its translation and commentaries, the Zand while others come from the spoken language and have acquired a technical meaning in the legal context. Yet other technical terms were coined in the daily practice of the law courts $(2005 \mathrm{a}$, p. 385; 2009a, 2010 b, p. 102f.).

MACUCH has published important editions of the Pahlavi version of chapters 5 and 12 of the Hērbedestān, the only Avestan text with a Pahlavi Zand which discusses matters relating to the religious education of Zoroastrians in greater detail (Macuch 2009b, 2009c). The problems arising from the poor transmission of the text, which only survives in few manuscripts, ${ }^{4}$ are compounded by the elliptical style of the Pahlavi commentary and the discrepancies in certain passages between the Avestan text, its Pahlavi translation, and the longer commentaries referring to the translated text. In spite of two relatively recent editions of this text, MACUCH maintains that a great number of legal terms occurring in it are still poorly understood.

She emphasizes that the Avesta constitutes the common foundation and constant point of reference of both Zoroastrian law and Zoroastrian religion. Moreover, Zoroastrian priests were trained in both disciplines to be legal and

4 For the transmission of the Hērbedestān, see Hintze 2009, p. $171 \mathrm{f}$. 
religious experts, rad and mowbed in one person. ${ }^{5}$ They had both juridicial and priestly authority, and their highest dignitaries were very influential at the top of the state's administrative hierarchy. Many of the Sasanian legal terms were formed in pre-Sasanian, indeed Old Iranian times and reflect an older stage of Zoroastrian law. MAcuch illustrates this point with the Av. expression $y \bar{o}$. $h \bar{e}$ pascaèta 'who (succeeds) him afterwards', which is quoted in MHD 21.4 and elsewhere in Pahlavi texts from a lost Av. context. The petrified Av. phrase is used as a general technical term to denote the legal successor of the paterfamilias regardless of the successor's gender and the form of succession involved. It retains, MACUCH argues, the meaning of an earlier period predating the development of the precise terminology which distinguishes between the direct succession of the 'son according to the law' (dádestān-pus) and the intermediary

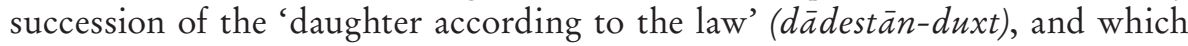
encodes the complex rules of succession as we know them from Sasanian times (Macuch 2003b, p. 234; 2005a, p. 377f.; 2014c, p. 86f.).

While the Avesta and its Zand have always been the theoretical foundation of Sasanian law and the ties between law and religion have remained close throughout the Sasanian period, Macuch argues that over the years jurisprudence gradually developed into a discipline in its own right, detached from religion, as the law code and legal practice grew more complex and the language increasingly technical. As a result, towards the end of the Sasanian period the discipline of jurisprudence was only loosely connected with religion. Court procedures and decisions that deviated from the theoretical foundation of the Avesta and Zand were labelled pad kardag 'according to practice', while pad čáštag 'according to doctrine' designated the canonical law and its interpretation by priests and jurisconsults. Likewise, offences were divided into the two groups. One comprised 'offences against opponents' (wināh ì hamèmālān), which were committed against fellow Zoroastrians, and the other 'offences against the soul' (wināh $\bar{\imath}$ ruwāning), which were committed against religious norms and endangered the soul of the delinquent (MACUCH 2003a, p. 173ff.; 2009a, p. 181f.; 2012a, p. 520; 2014b, p. 50).

Among the many Pahlavi terms whose meaning Macuch has clarified is the compound pabikār-rad, which WEST translated as 'magistrate in a dispute'. MACUCH 2002a, however, argues that in this compound the component pabikār has the technical meaning of 'legal dispute'. The compound pabikār-rad accordingly denotes a person 'involved in a judicial dispute', a 'litigant'. Moreover, she shows that it contrasts with a-pabikār-rad, which denotes a person who exercises the law himself without engaging in a judicial dispute. She identifies the antonymic pair as indicating the transition from the personal private law of blood feud and retaliation, to the formation of legal institutions at the early

5 Macuch 2014b, p. 51 provides a succinct survey of the different functions of a rad in Sasanian society. 
stages of the development of jurisprudence in Zoroastrian society. Another example of her detailed study of individual words is the examination of the Pahlavi term adwadad. She argues that its semantic range comprises not only the offence of 'abandoning (a person) on the road', which is the meaning of the term's Av. ancestor a $\delta \beta a d a \bar{i} t i-$, but also the shortage of food and drink, and the offences of failing in one's duty to provide food and drink to a person or an animal, or fuel to the sacred fire, or spiritual nourishment to a pupil (MACUCH 2012a, pp. 524-536; 2012b). MAcuch's refined understanding of Pahlavi legal technical terms has also benefited the interpretation of the Pahlavi model contract of a pādixšây-marriage, which is transmitted in the unique codex MK (MACUCH 2007). Although the contract is dated $1278 \mathrm{CE}$ and belongs to a time when jurisdiction of Zoroastrian communities was virtually confined to family law, Macuch argues that Sasanian technical terminology is used with full knowledge of all its legal implications. The article is an outstanding example of how the precise definitions of individual technical terms helps us to understand the text in the wider context of Sasanian jurisdiction. For example, she argues that the clause pad rāh $\bar{\imath} s t \bar{u} r \bar{\imath} h$ (ud) ayōgannīh in $\$ 2$ means neither "by way of guardianship and submission” (MAcKEnZIE) nor “... by way of being either a 'trustee' or an 'obligee" (PERIKHANIAN) but "by way of substitute succession (stūrīh) (or) intermediary succession (ayōgānīb)". The paragraph, MACUCH concludes, states that the $p \bar{a} d i x \bar{s} \bar{a} y$-bride transfers her reproductive capacity as both a stū $r$ and an ayōgen from her birth-family to the family of the bridegroom (МасUсн 2007, pp. 186, 193-195).

\section{Zoroastrian family law}

In a range of studies on Zoroastrian family law, MAcucH emphasizes the importance of the Zoroastrian religious ideas, promoted by the priesthood, which underpin the practice of marriage and inheritance in Sasanian Iran. She argues that the priesthood asserted and cemented its power in the state and its influence on the laity, by linking religious obligations with the social need and natural desire to preserve the basic structure of the family and of kinship groups. The entire system, she argues, served the dual purpose of maintaining the family property and of producing a male heir and successor. While the former is motivated by the material interests of powerful descent groups, the clergy and nobility in particular, the latter is underpinned by the society's patrilineal system and the religious doctrine that after death the soul of a man is unable to cross the bridge that connects this world and the next (Činwad Bridge) unless he has a male heir and successor whose duty it is to perform the death ceremonies for the soul of the deceased (2003b, pp. 235-236). The purpose of the Sasanian system of marriage is to ensure that it is virtually impossible for a man to die 
without leaving a son behind. Macuch maintains that the main reason for the overwhelming number of fictive ties lies in the obligation to ensure the continuity of a man's lineage (nāmburdārīb) and the performance of religious ceremonies in his name (namgānīb). ${ }^{6}$ Kinship practice and religion are thus linked together. Although such kinship practices are also found elsewhere, perhaps no other society has developed such a complex and elaborate system of constructed kinship to prevent the extinction of the male line. Showing the extent to which the two areas of inheritance law and family law are interrelated, Macuch reconstructs the complex Sasanian family structures as she extrapolates them from the Pahlavi legal texts.

Each Zoroastrian man was under the obligation to marry and have children and each woman was obliged to make her reproductive capacities available to the extended family. In the Pahlavi texts, endogamy and incest are promoted as the ideal means of keeping the family (paywand) 'pure' and guaranteeing the continuation of the race (tōhmag) of the Mazdaworshippers. The technical term xwēdōdah, which is absent from the Thousand Judgements, denotes various kinds of endogamous alliances, including those within the nuclear family (MAcuch 2010a). While the Zoroastrian priesthood promoted xwèdodah, MACUCH finds evidence suggesting that there were reservations among laypeople concerning incestuous alliances between members of the nuclear family (MACUCH 1991b, p. 151f.). One of the strategies used by the priests to make them a reality were temporary marriages, which were dissolved after a contractually agreed period of time (MACUCH 1991b, p. 153; 2006, p. 593f.). The institution of temporary marriage, MACUCH argues, was an integral part of Sasanian family law. In particular, she argues that temporary marriage provided additional options for procuring offspring, and was a means of using the female reproductive capacities to the full in the service of a patrilineal society. The general acceptance of incestuous alliances within the nuclear family is a fundamental prerequisite for the development of the elaborate system of intermediary succession (ayōgēnīh) and substitute succession (stū $r \bar{\imath} h)$, in which real and fictive incestuous ties and consanguinity were key factors (2003b, pp. 236-238). Every Zoroastrian woman was obliged to act as ayogeenn or stū $r$ when requested and enter a time-limited marriage in order to produce offspring for her deceased father, brother or husband (1995, pp. 153-155; 2006, p. 594f.).

MACuch 2014c examines four epic narratives of Ardaxšer's genealogy in the light of Zoroastrian family law. In order to be accepted as a legitimate successor of the Achaemenid dynasty, Ardaxšēr had to be genetically linked to Sāsān while at the same time belonging to the line of his official father Pābag. With the

6 The meaning and function of the term nāmgānīh has been elucidated by KLINGENsснмiтt 1971, pp. 145-150. Deriving the noun with suffix $-y b$ from an adj. "n'mk'n 'belonging to the name, being in relation to the name', he argues that nāmgānì denotes the death ritual. 
exception of aț-Tabarî̀s account, which is clearly patrilineal (grandfather Sāsān, father Pābag, son Ardaxšêr), in the versions of the Kārnāmag, Agathias and the Bundahišn genetic ties between Sāsān and Pābag are constructed through Ardaxšēer's mother. The latter is either the daughter/wife of Pābag (Kārnāmag, Agathias) or the daughter of Sāsān (Bundabišn). In the various scenarios of Ardaxšêr's descent, MACuCH argues, the most interesting feature is that the constructions of Ardaxšēr's Achaemenid descent are based on Sasanian legal practice and involve the female line in a patrilineal society.

MaCUCH emphasizes the significance of the system of Zoroastrian family law for our understanding of the social and political history of Sasanian Iran (MAcuch 1995). A case in point is her work on the legal implications of the revolt of Mazdak (2015b). Discussing the movement from the point of view of the accusations, preserved in the Dēnkard, made against the revolutionary by the Zoroastrian priesthood, she argues that when accusing the Mazdakites of overthrowing the complex rules of property and inheritance, the priests use precise legal terminology. She interprets this as indicating that the relevant passages (Dk 3.5.1-2 and 7.7.22-25) derive from an earlier Middle Persian text of the Sasanian period itself. Although the Dēnkard passages are short, the precise legal terminology used by the priests, and the accusations they make, speak of the existential threat which the movement posed to the Sasanian state. For by undermining all branches of jurisprudence and the institutions of marriage and inheritance, the Mazdakites attacked the very foundations of Sasanian society (1995, pp. 151f., 165f.).

\section{The Sasanian legal system}

Identifying the technical terms and meticulously studying their form and function constitutes the essential prerequisite for reconstructing the Sasanian law code. Maria Macuch explains her methodology as follows (Hintze 2014, p. 6):

From there [i.e. the study of the technical vocabulary] I proceed to putting the terms together into a system, trying to work out how they relate to one another. I aim at reconstructing the underlying legal system bit by bit, the unwritten code which is a constant point of reference for the Sasanian jurists but which nowhere in our extant sources is set out in a systematic fashion.

She presents her reconstruction of the Sasanian legal system in articles on "Vorislamisches iranisches Recht" (2013a) and on "Law in Pre-Modern Zoroastrianism" (2015c), and, as major contributions to the Encyclopaedia Iranica, in entries on "Charitable Foundations" (1991a), "Inheritance" (2005b), and, especially, on "Sasanian Legal System" (2009a). The most comprehensive discussion of the Sasanian legal system are her Ehsan Yarshater Lectures on Sasanian Law in its Social Context, delivered in the University of California 
at Los Angeles in November 2015. Arguing that the legal institutions were instrumental in consolidating the social status and power of Sasanian élites, notably the Zoroastrian clergy and the Iranian aristocracy, she discusses the Sasanian legal sources and instruments of law, kinship ties and fictive alliances, property and inheritance, civil and criminal proceedings, and the Sasanian law and other legal systems in general. The eventual publication of these lectures, which is currently under preparation, is bound to constitute a major milestone in the study of Sasanian law.

\section{Comparative law}

In the study of comparative law, MACUCH's research focuses on the relation between Zoroastrian Sasanian law, on the one hand, and Roman, Jewish, Eastern Christian, Byzantine and Islamic law, on the other. "There are certainly differences between Sasanian law and the legal systems of other cultures," she states (Hintze 2014, p. 6), "in particular with regard to family law, inheritance and succession, but I also detect similarities.” For example, in the field of property law, Macuch compares the Iranian distinction between 'ownership' (xwēš̄ and 'possession, holding, tenure' (dārišn) with the distinction between dominium, proprietas 'ownership' and possessio 'possession, holding, tenure' in Roman law, although she also notes differences (MACUCH 2008b, p. 129f.; 2015d, p. 248f.). Moreover, by adducing a parallel from Roman law she elucidates the Pahlavi term dastwar. Previously it was widely thought that the term, which means 'authority, priest, minister' in non-technical language, denotes a 'lawyer' or an 'advocate' in a general sense in legal contexts. However, the word's technical meaning had remained unrecognized. Through comparison with the function of Latin auctor in ancient Roman law, Macuch has been able to establish that in addition to the non-technical meaning, dastwar also has two technical meanings. In the context of property law it denotes 'a person who holds the entitlement' to the substance, income and disposal of a certain object, while in procedural law it designates the 'legal predecessor'. The latter is a person who in a lawsuit guarantees that an object he previously owned or possessed did not belong to a third party and was transmitted legally to the defendant (MACUCH 1988, 2005a, p. 384f.; 2008b, p. 134f.; 2010b, p. 105f.; 2015d, p. 249f.).

During ca. 1,200 years of the Achaemenid, Parthian and Sasanian periods Jews in Babylonia lived under Iranian rule in close proximity to Zoroastrians. The importance of the Iranian legal sources for understanding the Babylonian Talmud, the chief source for Jewish law and theology, is increasingly appreciated by scholars, one of the foremost among them being Maria MACUCH. This new evaluation is in stark contrast to ЈАсов Neusner's conclusion that Jews in Babylonia were little, if at all, influenced by the surrounding heterogeneous 
cultural environment (MACUCH 2010b, p. 101). A substantial part of MACUCH's work deals with the interactions of Zoroastrians and Babylonian Jews as reflected in the Babylonian Talmud. The latter employs a large number of Iranian loan words and loan translations taken from both everyday speech and the technical vocabulary of Iranian jurisprudence. МACUCH 1999 and 2002b argues that the Rabbis were familiar with the technical meaning of Iranian legal terms and used them in the same way as their Iranian counterparts. As a result, Iranian technical terms are as little explained in the Babylonian Talmud as they are in the Iranian legal texts. A case in point is the term dastwar, whose meaning MACUCH has elucidated with reference to Latin auctor, as discussed above, and its derivative dastwarīh. The latter term occurs as an Iranian loan word in two passages of the Babylonian Talmud and cannot be understood without considering the Iranian sources, from where it was borrowed. МACUCH 2008b, p. $135 \mathrm{f}$. argues that in the Babylonian Talmud dastwarih denotes the 'entitlement' to the substance or income of a certain object and the power of its disposal, and is used with the same technical meaning which the term has in Sasanian property law.

During the second half of the first millennium CE a sizeable Christian community existed in Persis, with most of its members possessing a family background of conversion from Zoroastrianism. These Middle-Persian speaking Christians had their own law book, the Corpus Iuris, which was compiled in Pahlavi by the archbishop of Persis, Jesubōxt, in the eighth century CE for the local Christian community. The work was translated into Syriac under the East Syrian patriarch Timotheos I. (727-823 CE), who was Catholicos of the Church of the East in 780-823 CE. Only the Syriac version survives to the present day, whereas the Pahlavi original is lost. The significance of Jesubōxt's Corpus Iuris for our knowledge of Sasanian law was already noted by EDUARD SACHAU, its editor and translator (SACHAu 1914). In an article published in the Festschrift for her father, MARIA argues that the Syriac translation of Pahlavi legal terms is very precise, and that the translator makes every effort to find the equivalent expression in Syriac without using the Pahlavi word (1989, p. 150). There are, however, rare occasions when the Pahlavi term is not translated but transliterated in Syriac script. One of them is abesaxwanīh, to which the entire chapter 6 of the Corpus Iuris is dedicated. Macuch links the Pahlavi word of the Syriac text with hitherto unnoticed attestations in the Thousand Judgements and defines its meaning as 'waiving of claims' ("Anspruchsverzicht", 1989, p. 157). Pointing out that the Corpus Iuris provides the key to our understanding of this term with regard to both its phonetic reading and its definition, she concludes that in the Hazār Dādestān the term chiefly occurs in contexts dealing with the law of obligations ("Schuldrecht"), while the meaning is more general in the Corpus Iuris, where it chiefly but not exclusively occurs in contexts concerned with the law of inheritance.

Macuch argues that the law code of the Persian Christians is based on Zoroastrian law, with the exception of Zoroastrian marriage law with its con- 
sanguineous and levirate marriages, which are vehemently rejected. She finds a clue for how deeply the law of the Persian Christians is rooted in Zoroastrian law in the same groupings of offspring. The categories of children denoted in the Corpus Iuris by Syriac (1) b-nāmusa 'according to law', (2) b-kyāna 'according to nature', and (3) $b-q \bar{u} b \bar{a} l \bar{a}$ 'through adoption' correspond exactly to the Zoroastrian categories (1) dādestān-pus/duxt 'son/daughter according to law',

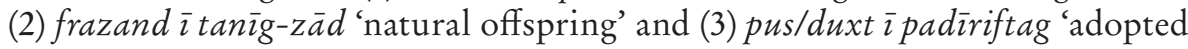
son/daughter' (Macuch 2003b, p. 242f.). The Syriac terms translate the Pahlavi ones and the Zoroastrian groupings of offspring are retained in the laws of the Persian Christians. Likewise, the evaluation of different types of seals found in Jesubōxt corresponds to that of the Hazār Dādestān (MACuch 1997, p. 84f.; 2010b, p. 104).

MACUCH 2014b is an intriguing study of the charges brought by Zoroastrian priests against Mār Ābā, the catholicos of the Church of the East in 540-552 and a Zoroastrian convert to Christianity. Probably of aristocratic descent, he served as a major state official under Husraw I Anōšagruwān (ruled 531-579). That Mār Ābā had the legalistic mindset of a Zoroastrian jurisconsult emerges from the way he refutes Zoroastrian marriage customs in his Syriac tractate on marriage laws, edited and translated by SACHAU 1914, pp. 255-285. This work includes a discussion of twenty types of conjugal alliances which were permitted by Zoroastrian law, but forbidden by Mār Ābā. Macuch notes that Mār $\bar{A} b \bar{b}$ 's description of Zoroastrian marriage alliances fully accords with what we know from the Pahlavi legal literature, but surpasses the latter in detail. Moreover, she argues that by attacking individual Zoroastrian marriage customs, Mār $\bar{A} b \bar{a}$ critically undermined the legal institutions that upheld them, in particular ayōgēnīh 'intermediary successorship' and stūrīh 'substitute successorship', which constituted the backbone of the Sasanian social system (2014b, pp. 52-54). Consequently, he was prosecuted by the mowbedan mowbed, the head of the Zoroastrian clergy and judiciary, and charged with high treason which was 'worthy of death' (margarzān).

Comparing the legal status of pious foundations in the Byzantine and Sasanian empires, MACUCH 2004 detects a range of parallels, almost all of which are later also found in the laws that govern the establishment and management of Islamic charitable foundations, or waqf. Both Byzantine and Sasanian law distinguish between public and private foundations. These foundations had an inalienable endow ment the income of which was used to cover the running costs of the establishment. While in Byzantine law the legal owner of public pious foundations was the Church, in the case of Zoroastrian fire foundations it was the fire itself ( $x w \bar{e} s \bar{s} \bar{\zeta} \bar{\imath} \bar{a} \operatorname{taxs}$ ' ownership of the fire', p. 194). Certain fire-temples had huge possessions and played a significant role in the economy of Sasanian Iran. MACUCH argues that Shiite Islamic charitable foundations are strikingly similar to religious charitable foundations of the Sasanian period, the most salient feature being a shared underlying structure. This includes the view that 
property consists of two parts: the substance (bun 'principle') and the increase (bar 'fruit'). At the root of this distinction lies the Sasanian requirement that the endowment, which is the substance, is inalienable and cannot be changed or spent. The distinction between the notions of bun and bar is deeply tied up with the Zoroastrian system of inheritance and succession and is also found in Talmudic law (MAcuch 2015d). Likewise, in Shiite Islam the institution designated with the Arabic term waqf represents fixed, inalienable property, while the interest or gain from this property may be spent and is at the disposal of the heirs and successors (MACUCH 1994, 2009d).

The institution of temporary marriage, which MAcuch has shown to have been an integral part of Sasanian family law, is also found up to the present day, as a distinct legal institution of a special form of marriage in Twelver Shiite jurisprudence, where it is called mut'a 'enjoyment' and șìge in Arabic and Persian sources respectively. Such a union may last between one hour and 99 years. Its practice is confined to Shiites in Iran and is not found among the Shiites outside Iran, while Sunni legal experts reject it as alien to Islamic law. Children born of the $m u t^{\prime} a$ are considered to be legitimate children of the father. MACUCH argues that temporary marriage adopted into Shiite jurisprudence has its origin in the Sasanian tradition. She supports this view with parallels which she identifies between different types of temporary marriage in Sasanian Iran and the Shiite $m u t^{\prime} a$ and concludes that these parallel are unlikely to be accidental (MACUCH 1985, 2006, p. 585f.). She also argues that the law of succession in Shi ite jurisprudence is based to a considerable degree on Zoroastrian customary law (Macuch 2017a). That Zoroastrian Sasanian law continued to be practised in Iran at least during the first two centuries of the Islamic period has been confirmed by the unique Tabarestān court records, whose legal context is examined by MACUCH 2016b and 2017b.

\section{Iranian literature}

Maria Macuch has provided two valuable surveys of Pre-Islamic Iranian literatures (2009e and 2013b). While women are usually represented in Pahlavi literature as lacking intellectual capacities that go beyond the standard religious knowledge, MACuCH $2009 \mathrm{f}$ discusses an episode related in the Hazār Dādestān that deviates from this stereotype. The story involves three women sitting at the roadside and engaging men passing by in a discussion about complex legal problems which, however, remain unsolved. Although the questions they raise are real questions, MACUCH argues that the woman represent a literary topos of symbolic rather than real persons. In demonstrating the limits of the discipline of law to the learned jurisconsults, they embody the enigmatic side of the discipline of jurisprudence. 
Macuch examines the representation of the Turcs in Pahlavi literature against the background of the Zoroastrian world-view (MACUCH 2016a), and the search for and experiences with God in Persian Sufi poetry (Macuch 2000). Her works on Persian poetry also include a study of the imagery in Persian mystical poetry (MACUCH 1998) and of the pre-Islamic roots of Firdausi's Šănname (MACUch 2011a and 2012c). In the latter article, which was published in German and in English, she points out that the Šăhname not only draws on Iranian traditions of individual figures, but also promotes Zoroastrian concepts and values, including the opposition between Good and Evil, truth and lie, and the concept of the legitimate, righteous ruler. The latter is defined by the king's patrilineal descent from the ruling dynasty and the possession of the aureole of kingship, the xwarrah, the king's charisma that is awarded to him by God.

\section{Other academic achievements}

For more than twenty years until her retirement in 2015, MARIA MACUCH taught Iranian Studies at the Institut für Iranistik of the Freie Universität Berlin with a focus on Middle and New Persian languages and literature. She was supported in her work by a competent team of colleagues, including FARIFTEH TAFAKOLli, Feryad Omar, Götz König, Iris Colditz and Maryam MameghanianPrenzlow. Many of us, students and colleagues alike, have benefited not only from her immense scholarship but also from her friendship and unstinting support. Thus, soon after the fall of the Berlin Wall in 1989, she arranged for WeRNER Sundermann to become an Honorary Professor of the Freie Universität to share his profound knowledge of Manichaeism and Iranian languages with the students. Several years later she made the same arrangements for WERNER SUNDERmanN's successor at the Berlin-Brandenburg Academy of Sciences, Desmond Durkin-Meisterernst. Together with the latter and other colleagues, she set up a structured three-year doctoral programme "Languages and Cultures of the Silk Road" at the Berliner Antike-Kolleg for PhD candidates in the fields of Iranian, Turkish and Central Asian Studies, and East Asian Art, enlisting the enormous resources of academic experts and source materials at the Berlin-Brandenburgische Akademie der Wissenschaften, especially the Turfan Studies project, the Staatsbibliothek zu Berlin, the Humboldt Universität, the Freie Universität, the Deutsche Archäologische Institut and the Staatliche Museen zu Berlin. Moreover, together with colleagues of the Freie Universität, she participated in the collaborative research project "Episteme in movement" ("Episteme in Bewegung"), which gave IRIs Colditz and Benjamin JoKISCH the opportunity to carry out research projects on the interactions between Zoroastrian and Islamic law. Furthermore, Maria Macuch has secured 
external funding for individual research projects and their publication in her series Iranica. Successful projects include the work of Dieter Weber on Berliner Pablavi-Dokumente (Iranica 15), of David Buyaner on the Patet texts of the Khorde Avesta (Iranica 22) and of Miguel Ángel Andrés-Toledo on the Pahlavi Widèrodād (Iranica 23). All these activities, both within Iranian Studies and on an interdisciplinary level, have greatly contributed to the high standing which Iranian Studies at the Freie Universität enjoy both nationally and internationally. Being fully aware that it was nevertheless not to be taken for granted that Old and Middle Iranian Studies would continue to be covered at the University after her retirement, she successfully made every effort to defend the interests of our subject. With the appointment of her successor, Alberto Cantera, the continuity of Old and Middle Iranian Studies in Berlin has been secured at least for the foreseeable future.

To date 26 volumes have been published in the series Iranica, which MARIA Macuch founded in 1993 and which she now co-edits with Alberto Cantera. The wide range of topics covered includes editions of Avestan and Middle Persian texts, studies of Iranian grammar, religion and society, conference volumes, festschrifts and memorial volumes. Layout and typesetting of the volumes are taken care of at the Institut für Iranistik and, since the series's inception have been the responsibility of Claudius Naumann, and in recent years also of Tatsiana Harting. Made to high specifications in outer appearance, and with high academic standards in their contents, the volumes constitute important contributions to Iranian Studies and are highly regarded internationally, with many libraries around the globe holding standing subscriptions. Moreover, Maria Macuch has served as co-editor of a Festschrift (Macuch 1989), a memorial volume (MACUCH 2007), a collective work on Pre-Islamic Iranian literature (MACUCH 2009e) and a conference volume (MACUCH 2011b).

Maria MACUCH is a member of a wide range of academic and professional organisations, including the Corpus Inscriptionum Iranicarum, the Deutsche Morgenländische Gesellschaft, the Advisory Board of the Orient-OkzidentGesellschaft, and the Societas Iranologica Europaea, where she served as president from 2003 to 2007. In 2013 she was elected an Honorary Fellow of the Ancient India and Iran Trust (Cambridge, England).

\section{References}

Anklesaria, T.D. 1912: The Social Code of the Parsis in Sassanian Times or Màdigān i Hazār Dādistān. Part II. Bombay.

Dhabhar, B. N. 1923: Descriptive Catalogue of all manuscripts in the First Dastur Meherji Rana Library, Navsari. Bombay.

Hintze, A. 2009: “Disseminating the Mazdyasnian religion: An edition of the Avestan Hērbedestān Chapter 5.” In: W. Sundermann/ A. Hintze/ F. De Blois 
(eds.): Exegisti monumenta. Festschrift in Honour of Nicholas Sims-Williams. Wiesbaden (Iranica 17), pp. 171-190.

- 2014. "Meet our new Honorary Fellow. Professor Maria Macuch in conversation with Almut Hintze, 13 December 2013.” In: Indiran. The Newsletter of The Ancient India and Iran Trust 9, pp. 6-7.

Hjerrild, B. 2002: Studies in Zoroastrian Family Law: A Comparative Analysis. Copenhagen (Carsten Niebuhr Institute Publications).

JamaspAsa, K.M./M. Nawabi 1976: Manuscript F25. Matikan i Hazar Datastan, Ashem Vobu, etc. Shiraz (The Pahlavi Codices and Iranian Researches vol. 31).

Klingenschmitt, G. 1971: “Neue Avesta-Fragmente (FrA.).” In: MSS 29, pp. 111-174.

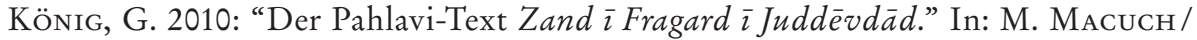

D. Weber/D. Durkin-Meisterernst (eds.): Ancient and Middle Iranian Studies. Proceedings of the $6^{\text {th }}$ European Conference of Iranian Studies, held in Vienna, 18-22 September 2007. Wiesbaden (Iranica 19), pp. 115-132.

Macuch, M. 1981: Das Sasanidische Rechtsbuch "Mātakdān i Hazār Dātistān" (Teil II). Wiesbaden (AKM XLV,1).

- 1985: "Die Zeitehe im sasanidischen Recht - ein Vorläufer der šícitischen $m u t^{c} a$-Ehe in Iran?” In: $A M I$ 18, pp. 187-203.

- 1988: “Der dastwar, ,auctor', im sasanidischen Zivilprozeß.” In: AMI 21, pp. 181-192.

- 1989: "Ein mittelpersischer terminus technicus im syrischen Rechtskodex des

İšōbōht und im sasanidischen Rechtsbuch.” In: M. Macuch/C. Müller-

Kessler/B.G. Fragner (eds.): Studia Semitica necnon Iranica Rudolpho

Macuch septuagenario ab amicis et discipulis dedicata. Wiesbaden, pp. 149-160.

- 1991 a: "Charitable Foundations in the Sasanian Period." In: EIr V, Fasc. 4. Costa

Mesa, California, pp. 380-382.

- 1991 b: “Inzest im vorislamischen Iran.” In: AMI 24, pp. 141-154.

- 1993: Rechtskasuistik und Gerichtspraxis zu Beginn des siebenten Jabrbunderts in Iran. Die Rechtssammlung des Farrobymard $i$ Wabrāmān. Wiesbaden (Iranica 1).

- 1994: "Die sasanidische Stiftung ,für die Seele - Vorbild für den islamischen waqf?"

In: P. VAVRoušE (ed.): Iranian and Indo-European Studies: Memorial Volume of Otakar Klima. Praha, pp. 163-180.

- 1995: "Herrschaftskonsolidierung und sasanidisches Familienrecht: zum Verhältnis von Kirche und Staat unter den Sasaniden.” In: CHr. Reck/P. Zieme (eds.): Iran und Turfan: Beiträge Berliner Wissenschaftler, Werner Sundermann zum 60. Geburtstag gewidmet. Wiesbaden (Iranica 2), pp. 149-167.

- 1997: “The Use of Seals in Sasanian Jurisprudence.” In: R. Gyselen (eds.): Sceaux

d'orient et leur emploi. Bures-sur-Yvette (Res orientales 10), pp. 79-87.

- 1998: “Zur Bildersprache der persischen mystischen Dichtung." In: A. Hölscher/

R. Kampling (eds.): Religiöse Sprache und ibre Bilder: Von der Bibel bis zur modernen Lyrik. Berlin (Schriften der Diözesanakademie Berlin 14), pp. 175-199.

- 1999: "Iranian Legal Terminology in the Babylonian Talmud in the Light of

Sasanian Jurisprudence.” In: SH. Shaked/A. Netzer (eds.): Irano-Judaica IV: Studies Relating to Jewish Contacts with Persian Culture Throughout the Ages. Jerusalem, pp. 91-101.

- 2000: “Gottes-Suche und Gottes-Erfahrung in der persischen Sufi-Dichtung.” In:

M. Delgado/A.P. Kustermann (eds.): Gottes-Krise und Gott-Trunkenheit: 
Was die Mystik der Weltreligionen der Gegenwart zu sagen hat. Würzburg, pp. 134-158.

- 2002a: "A Zoroastrian Legal Term in the Dēnkard: pahikār-rad." In: PH. Huyse

(ed.): Iran: Questions et connaissances. Vol. I: La période ancienne. Paris (StIr, Cahier 25), pp. 77-90.

- 2002b: “The Talmudic Expression 'Servant of the Fire' in the Light of Pahlavi

Legal Sources.” In: JSAI 26 (= Volume in Honour of Shaul Shaked), pp. 109-129.

- 2003a: "On the Treatment of Animals in Zoroastrian Law." In: A. van TONGERLOo

(ed.): Iranica Selecta: Studies in honour of Professor Wojciech Skalmowski on the

occasion of his seventieth birthday. Turnhout (Silk Road Studies 8), pp. 167-190.

- 2003b: "Zoroastrian Principles and the Structure of Kinship in Sasanian Iran."

In: C. G. Cereti/M. Maggi/E. Provasi (eds.): Religious Themes and Texts of pre-Islamic Iran and Central Asia: Studies in honour of Professor Gherardo Gnoli on the occasion of his $65^{\text {th }}$ birthday on 6 December 2002. Wiesbaden (Beiträge zur Iranistik 24), pp. 231-246.

- 2004: “Pious Foundations in Byzantine and Sasanian Law.” In: GH. Gnoli (ed.):

La Persia e Bisanzio. Convegno internazionale, Roma, 14-18 ottobre 2002. Roma

(Atti dei convegni Lincei 201), pp. 181-196.

- 2005a: “On Middle Persian Legal Terminology.” In: C.G. Cereti/M. Maggi

(eds.): Middle Iranian Lexicography: Proceedings of the Conference beld in Rome,

9-11 April 2001. Roma (Orientalia Romana 8), pp. 375-386.

- 2005b: “Inheritance. i. Sasanian Period.” In: EIr XIII, pp. 125-131.

- 2006: "The Function of Temporary Marriage in the Context of Sasanian Family

Law." In: A. Panaino/A. Piras (eds.): Proceedings of the Fifth Conference of the Societas Iranologica Europaea held in Ravenna, October 6-11, 2003. Vol. I: Ancient and Middle Iranian Studies. Milano, pp. 585-597.

- 2007: “The Pahlavi Marriage Contract in the Light of Sasanian Family Law." In:

M. Macuch/M. Maggi/W. Sundermann (eds.): Iranian Languages and Texts

from Iran and Turan. Ronald E. Emmerick Memorial Volume. Wiesbaden (Iranica 13), pp. 183-204.

- 2008a: "Rudolf Macuch." In: R. Voigt (ed.): Und das Leben ist siegreich! / And

Life is Victorious. Mandäische und samaritanische Literatur / Mandean and

Samaritan Literature. Im Gedenken an Rudolf Macuch / In Memory of Rudolf Macuch (1919-1993). Wiesbaden, pp. 9-16 (Mandäistische Forschungen 1).

- 2008b: "An Iranian Legal Term in the Babylonian Talmud and in Sasanian Jurisprudence: dastwar.” In: SH. SHA Ked / A. Netzer (eds.): Irano-Judaica VI: Studies Relating to Jewish Contacts with Persian Culture Throughout the Ages. Jerusalem, pp. 126-138.

- 2008c: "Zur juristischen Terminologie der Berliner Pahlavi-Dokumente." In:

D. Weber: Berliner Pablavi-Dokumente. Zengnisse spätsassanidischer Briefund Rechtskultur aus frühislamischer Zeit. Wiesbaden (Iranica 15), pp. 249-266.

- 2009a: "Judicial and Legal System. iii. Sasanian Legal System.” In: EIr XV, pp. 181-196. - 2009b: "Disseminating the Mazdayasnian Religion: An Edition of the Pahlavi Hērbedestān Chapter 5.” In: W. Sundermann/ A. Hintze/ F. De Blois (eds.): Exegisti monumenta. Festschrift in Honour of Nicholas Sims-Williams. Wiesbaden (Iranica 17), pp. 251-277. 
-2009c: "The Hērbedestān as a Legal Source: A Section on the Inheritance of a Convert to Zoroastrianism.” In: BAI 19 (2005) [2009] (= Iranian and Zoroastrian Studies in Honor of Prods Oktor Skjarvø, ed. by C.A. Bromberg, N. SimsWilliams and U. Sims-Williams), pp. 91-102.

- 2009d: "Die sasanidische fromme Stiftung und der islamische waqf: Eine Gegenüberstellung.” In: A. Meier/J. Pahlitzsch/L. Reinfandt (eds.): Islamische Stiftungen zwischen juristischer Norm und sozialer Praxis. Berlin, pp. 19-38.

- 2009e: "Pahlavi Literature." In: R. E. Emmerick/M. Macuch (eds.): The Literature of Pre-Islamic Iran. Companion Volume I to A History of Persian Literature. London 2009 (History of Persian Literature XVII), pp. 116-190.

- 2009f. "Gelehrte Frauen: ein ungewöhnliches Motiv in der Pahlavi-Literatur." In: D. Dur kin-Meisterernst / Chr. Reck / D. Weber (eds.): Literarische Stoffe und ibre Gestaltung in mitteliranischer Zeit. Kolloquium anlässlich des 70. Geburtstages von Werner Sundermann. Wiesbaden (Beiträge zur Iranistik 31), pp. 135-151.

- 2010a: "Incestuous Marriage in the Context of Sasanian Family Law." In: M. Macuch / D. Weber/D. Durkin-Meisterernst (eds.): Ancient and Middle Iranian Studies. Proceedings of the Sixth Europaean Conference of Iranian Studies of the Societas Iranologica Europaea in Vienna, Sept. 19-22, 2007. Wiesbaden (Iranica 19), pp. 133-148.

- 2010b: "Allusions to Sasanian Law in the Babylonian Talmud." In: C. BAKhos / M.R. Shayegan (eds.): The Talmud in its Iranian Context. Tübingen, pp. 100-111. - 2011 a: “Die vorislamischen Wurzeln des Schāhnāme von Ferdausi.” In: J. Gonnella/ $\mathrm{C}_{\mathrm{H}}$. Rauch (eds.): Heroische Zeiten. Tausend Jahre persisches Buch der Könige. Berlin, pp. 22-27.

- 2011b (ed., with D. Weber and D. Durkin-Meisterernst): Ancient and Middle Iranian Studies. Proceedings of the 6th European Conference of Iranian Studies, beld in Vienna, 18-22 September 2007. Wiesbaden (Iranica 19).

- 2012a: "Editing Pahlavi Legal Texts." In: A. Cantera (ed.): The Transmission of the Avesta. Wiesbaden (Iranica 20), pp. 519-540.

- 2012b: "The adwadadd Offence in Zoroastrian Law." In: SH. SEcunda/ST. Fie (eds.): Shoshannat Yaakov. Jewish and Iranian Studies in Honor of Yaakov Elman. Leiden/Boston (The Brill Reference Library of Judaism 35), pp. 247-269.

- 2012c: “The Pre-Islamic Roots of Firdausi's Shabnama." In: J. Gonnella/ Ch. Rauch (eds.): Heroic Times. A Thousand Years of the Persian Book of Kings. Berlin, pp. 22-27.

- 2013a: "Vorislamisches iranisches Recht." In: L. Paul (ed.): Handbuch der Iranistik. Wiesbaden, pp. 123-132.

- 2013b: “Iranische Literaturen in vorislamischer Zeit.” In: L. PAul (ed.): Handbuch der Iranistik. Wiesbaden, pp. 281-311.

- 2014a: “,Behalte den Flug in Erinnerung ...' - Leben und Werk von Rudolf Macuch.” In: Sláva šlachetným III. Znalci vzdialenébo Orientu a strážkyne národnébo obniska. Slovenski orientalisti a aktivity spolku Živena. Liptovský Mikuláš, pp. 61-72.

- 2014b: "The Case against Mār Abā, the Catholicos, in the Light of Sasanian Law." In: ARAM. Zoroastrianism in the Levant and the Amorites, vol. 26.1\&2. Oxford, pp. $47-58$. 
-2014c: “Ardashir's Genealogy Revisited.” In: P. Pourshariati/M. TAvakoli (eds.): Iran Nameh 29, A Special Issue Honoring Jaleb Amouzgar, pp. 80-94.

- 2015a: "Rudolf Macuch (1919-1993)." In: P. Bunovec (ed.): Christlicher Orient im Porträt - Wissenschaftsgeschichte des Christlichen Orients. Kongreßakten der 1.Tagung der RVO (4.Dezember 2010, Tübingen). Hamburg, Teilband 2, pp. 1035-1054.

- 2015b: "Legal Implications of Mazdakite Teaching According to the Dénkard." In: Chr. Jullien (ed.); Husraw I ${ }^{e r}$. Reconstructions d'un Règne. Sources et Documents. Paris (Studia Iranica, Cahier 53), pp. 155-174.

- 2015c: "Law in Pre-modern Zoroastrianism." In: M. Stausberg/Y.S. D. Vevaina (eds.): The Wiley Blackwell Companion to Zoroastrianism. Oxford, pp. 289-298.

- 2015d: "Substance and Fruit in the Sasanian Law of Property and the Babylonian Talmud." In: M.J. Geller (ed.): The Archaeology and Material Culture of the Babylonian Talmud. Leiden/Boston, pp. 245-259.

- 2016a: “Türken in der zoroastrischen Literatur." In: I. HauensCHILd/M. KAPPLER/ B. Kellner-Heinkele (eds.): Eine bundertblättrige Tulpe - Bir șadbarg lāla. Festgabe für Claus Schönig. Berlin, pp. 308-331.

- 2016b: “The Legal Context of the Tabarestan Court Records (Tab. 1-8,10)." In: R. Gyselen (ed.): Words and Symbols: Sasanian Objects and the Tabarestan Archiv Gyselen. Bures-sur-Yvette (Res Orientales XXIV), pp. 145-169.

- 2017a: "Descent and Inheritance in Zoroastrian and Shiite Law: a Preliminary Study.” In: Der Islam 94 (2), pp. 322-335.

- 2017b: "Pahlavi Legal Documents from Tabarestān on Lease, Loan and Compensation: the Juristic Context (Tab. 13,14, 15, 17, 18, 23).” In: R. Gyselen (ed.): Sasanian Coins, Middle-Persian Etymology and the Tabarestān Archive. Bures-surYvette (Res Orientales XXVI), pp. 165-195.

- Modi, J.J. 1901: Mâdigân-i-Hazâr Dâdîstân. A Photozincographed Facsimile of a Ms. belonging to the Mânockji Limji Hoshang Hâtariâ Library in the Zarthoshti Anjuman Atashbeharâm. Poona.

- SACHAU, E. 1914: Syrische Rechtsbücher. Vol.3: Corpus juris des persischen Erzbischofs Jesubocht. Erbrecht oder Canones des persischen Erzbischofs Simeon. Eherecht des Patriarchen Mar Âbhâ. Berlin. 